\title{
Features of Including the Religious Component in the Educational Process
}

\section{Levitskaya A*}

Department of Philosophy, Moscow State Regional University, Russia

*Corresponding author: Aleksandra Levitskaya, Assistant professor of philosophy department, Moscow State Regional University, Russia,Email: dafna_89@mail.ru
Commentary

Volume 3 Issue 4

Received Date: September 23, 2020

Published Date: October 06, 2020

DOI: $10.23880 /$ abca-16000139

\section{Commentary}

The modern education system, solving the problems of training effective specialists and forming the necessary level of culture and civic loyalty of the individual, faces the need to pay attention to preparing students to meet the phenomenon of religious faith in the conditions of modern Russian society traditionally multi-confessional and multinational.

At the present time, decisions to include a religious component in the process of education and upbringing are implemented on the basis of pragmatic management decisions made in accordance with the vectors of official state policy and taking into account some results of theological experience, but without focusing on the methodological ideas of Russian science, since they are only being created. The practice of education and upbringing shows that the inclusion of religious knowledge in the learning process takes place with the more active participation of representatives of religious organizations, who sometimes have to take priority in this process due to the unwillingness of secular educational bodies to conduct a well-thought-out and balanced policy of forming a world view.

The Russian education system, which is being reformed according to Western standards with varying degrees of effectiveness, is still distinctive and unique, since it operates in a society where multi-faiths are combined with the dominance of one denomination, where the role of religion in the history of the state and society is very high and, in most cases, positive, and a long historical stage in cultural policy is characterized as anti-religious. The methodology of religious education research is based on several main provisions, the content of which is as follows:

1. Religious education is a part of humanitarian education that is experiencing a crisis in modern Russian society;

2. The content and role of religious education is determined by the ratio of secularism and religiosity in the space of modern culture and the entire system of social relations; 3 ) religious education, like any educational process, is organized by entities that are able to constantly normalize, Finance and control its course in changing conditions.

Based on these reasons, it is reasonable to conclude that the content of the term "religious education" is multilevel, and it can be viewed from several angles-which are confirmed by the study of various concepts. The explication of the concept of "religious education", despite the very long life of this phenomenon, is still a subject of discussion. In research practice, there are several definitions of religious education that are actively used, the authors of which are theologians, sociologists, teachers, and philosophers. These definitions are divided according to how religious education is interpreted: as a part of education (without antagonism to secular knowledge), or as a "competitor" of secular education (especially religious studies); as teaching religion only for the purpose of becoming a Church, or as teaching culture and morality (and, therefore, inseparable from religious studies).

Representatives of the Church have traditionally considered religious education as a professional education in the preparation of clergy and additional educational education for young people in the Church. This understanding is characteristic not only of Orthodox theology, or more broadly of Christian theology, but also of Muslim, Jewish, Buddhist, and so on. A similar point of view is shared by researchers in those countries whose official ideology has never severed ties with religion and the Church. For example, the Oxford encyclopedia gives this definition: "Religious education in schools and other educational institutions controlled by religious organizations, or teaching in a 
religious spirit" [1]. Paradoxically, in Soviet times, Russian science formulated [2] and still uses a definition that is quite consistent with the traditional Church understanding. It is as follows: "Religious education is an educational system, based on the tenets of one particular religion.

Religious education includes the study of theological disciplines and the performance of religious rites [3]. Close to this is the definition of religious education as an educational system based on the tenets of a particular religion. From this point of view, religious education (knowledge about the history, dogmas, morals, rituals, and other features of religion, presented without criticism of the content) is necessary and valuable only for believers and clergy of a particular religion. The reality is that there is a high public demand for knowledge about religions. Therefore, at the moment, responding to objective processes in the sociocultural life of society, both secular scientists and theologians are changing their view of the content of the term "religious education".

The secular and religious in the practical sphere interact in the cultural space through the participation of believers and non-believers in the production of knowledge and the transfer of information in the educational process. The state, through its education system, must provide its citizens with reliable and sufficient knowledge about the religions that exist in this society and in the world as a whole. Recognition of the obvious belonging of knowledge about religions to the complex of humanitarian knowledge that provides cultural self-identification of a person should increase not only the General cultural, but also the professional competence of future specialists [4]. The optimal principles of the secular teaching of basic knowledge on the beliefs and worship of certain religions are tolerance, multi-culturalism, mix of respect for individual rights on an ideological choice and recognition of the responsibilities of the individual to contribute to the progressive development of society, supporting its activities, the peace, harmony, understanding and mutual respect.

\section{References}

1. (2002) Fundamentals of the social concept of the Russian Orthodox Church. Religion in modern society, pp: 91.

2. Furov VG (2015) Religious training and education.

3. Hoggart R (2002) Peoples and cultures.

4. Arnoldov AI (2012) Humanitarian Education-sociocultural Phenomenon. Humanitarian space 1(2): 249261.

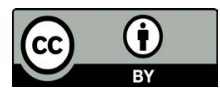

